\title{
Developing City Branding Strategy of Ternate in North Moluccas - Indonesia
}

\author{
ELI JAMILAH MIHARDJA \\ TUTI WIDIASTUTI \\ PRIMA M. AGUSTINI \\ Universitas Bakrie, Indonesia
}

\begin{abstract}
The city of Ternate has an interesting long history supported by beautiful natural scenery and rich culture. However, these days, Ternate has not yet identified its identity and branding. Storytelling is one of the instruments to form city branding (Keskin et al., 2016). Given the potential of the long history, cultural and natural wealth of Ternate, storytelling can be used as a strategy to form city branding. The research methodology used in this research is a case study. Data was collected through in-depth interviews, observation, and literature study. Fieldwork was carried out in Ternate and surrounding areas in September 2019. Data was analysed using the City's Core Story (Keskin, Akgun, Zehir \& Ayar, 2016). The results show that the city of Ternate has suitable material to develop this storytelling method because of its historical and cultural richness, although in its regional planning this is not a priority. It is interesting to develop the historical plot owned by Ternate in storytelling as a tool for city branding strategy, by compiling a plot as a part of the story. This is appropriate when the City of Ternate stakeholders are conducting a study of the city branding of Ternate. The results of the study could be used as recommendations for policy makers in Ternate regarding storytelling strategies to form city branding. These are also a novelty in developing city branding strategy in Indonesia.
\end{abstract}

Keywords: Storytelling, city branding, Ternate city, city core strategy, a plot of storytelling.

\section{INTRODUCTION}

Several local governments in Indonesia have begun to feel it necessary to form city branding (Mihardja, Bintoro, Putri, Widiastuti, Agustini, \& Adriat, 2019; Christin \& Fiteriadi, 2017). The same is also true with Ternate. At the time of carrying out this field work, it was known that Ternate was trying to compile its city branding through various events. There are also several studies that explain the efforts to compile this city branding (Erlangga, 2016; Astuti \& Ramos, 2012). However, using storytelling as a strategy of developing Ternate city branding has never been done. In fact, Ternate really has the potential to be developed by storytelling. Moreover, storytelling is also very suitable to be applied to the kind of city with long history such as Ternate (Pînzaru, 2012).

Ternate Island has a long history. From time to time, this spice-rich island was fought over by various nations from Europe. Ternate became the world's spice trade route with consequences for various events that enriched the region's history and culture, in fact, even to the present.

Long before the Christian era, the archipelago was known in India, the Middle East and Europe as a producer of spices, sandalwood and gold. Perhaps, gold is produced in many places on this earth, but spices, sandalwood, and other fragrant wood may only be produced on the archipelago, as the experts say.

In ancient times, there had been voyages to travel around the world from one point back to that point around the globe, the voyage was known as the Magelhaens Expedition. The voyage around the globe turned into a Gold, Glory and Gospel competition (wealth, glory, 
and spread of religion) among Europeans so that the Tordesillas Treaty (1494) was born. This agreement divides the two spheres of the Earth in the interest of Spanish and Portuguese powers.

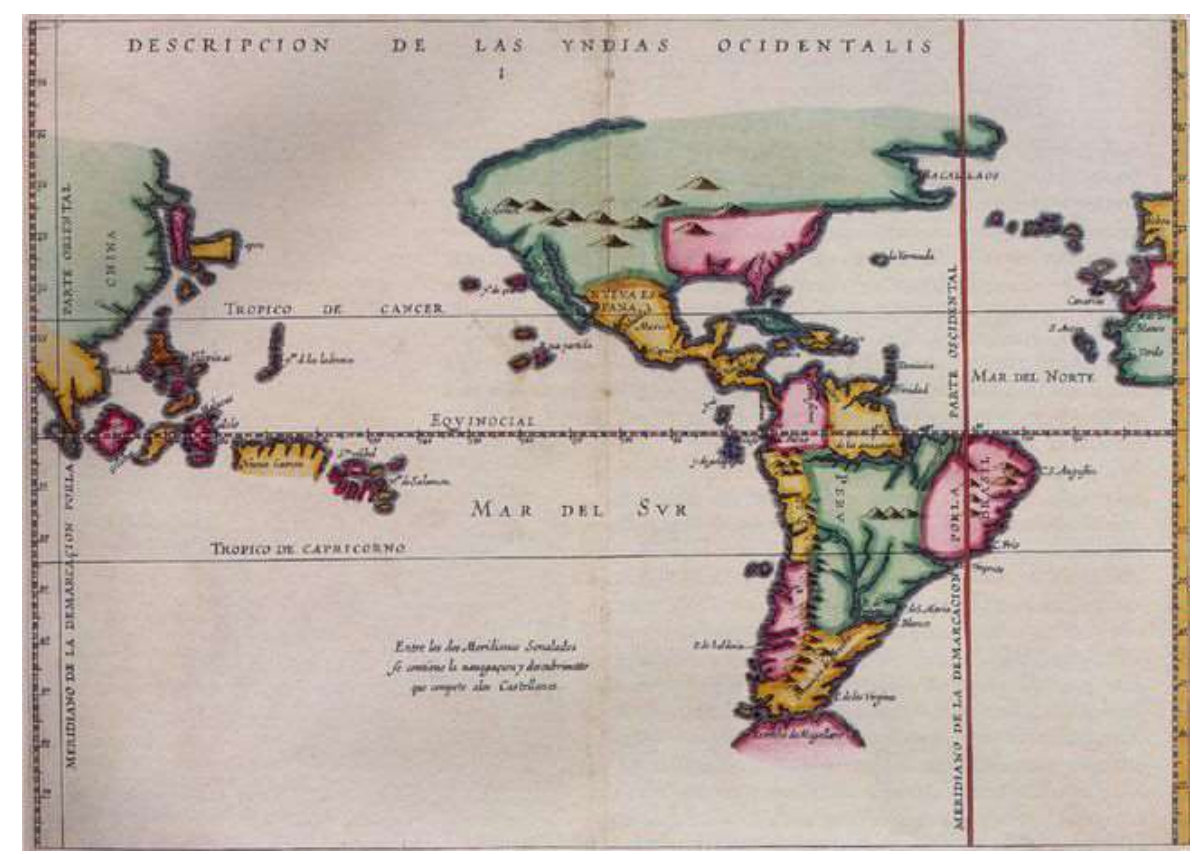

Figure 1: The Treaty of Tordesillas (source: National Geographic Society)

According to the Ternate City Development Planning Agency (BAPPEDA) (2012), the city of Ternate is located between 3 degrees Northern Latitude and 3 degrees Southern Latitude and 124 - 129 degrees Eastern Longitude. Ternate City borders the Maluku Sea in the north, south and west, and the Halmahera Strait in the east. As an Island City, Ternate consists of 8 (eight) islands, namely: five inhabited islands of Ternate as the main island, Hiri, Moti, Mayau, and Tifure, and three small uninhabited islands of Maka, Mano and Gurida. The territory of Ternate City covers $5,795.4 \mathrm{~km}^{2}$, consisting of $5,544.55 \mathrm{~km}^{2}$ of waters and 250.85 $\mathrm{km}^{2}$ of land.

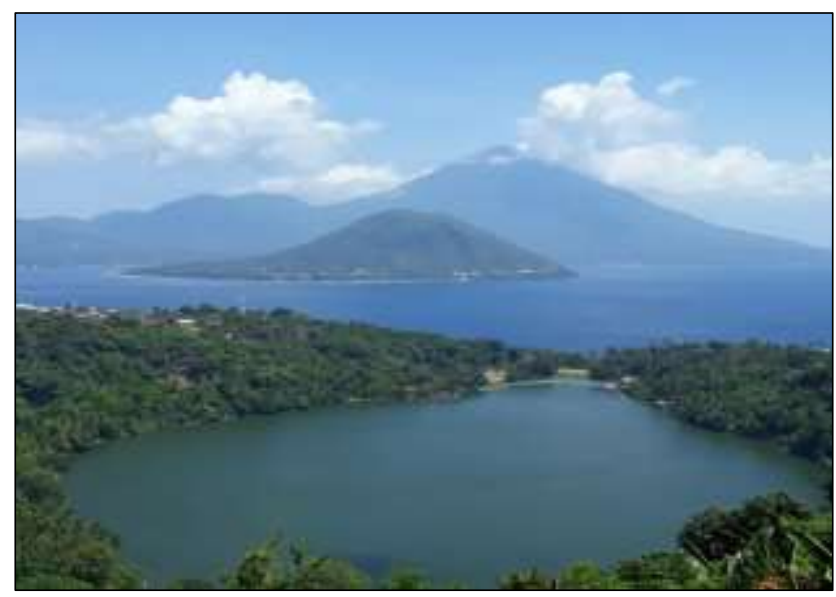

Figure 2: Scenery of Fhitu, Ternate (source: Personal Documentation) 
Mount Gamalama is an active volcano located in the center of Ternate Island. Human settlements have grown intensively along the coastline of the island. Ternate City is mostly made up of waters so that its climate is strongly influenced by the marine climate and the cycle of two seasons, namely North-West and East-South monsoon, which is often interspersed by two transition periods each year (BAPPEDA Ternate, 2012).

The history of this city began when the Sultanate of Ternate was founded around the 13th century on the island of Ternate, which made the city the seat of government. Kornelis Matelief de Jonge in 1607 built a fort in the city, which was named Fort Oranje. The fort was previously named Malayu (Hasyim, 2019).

The kingdom of Ternate played an important role in the North Maluku region until the 17th century. In the historical records of the Sultanate of Ternate or also defended with the Kingdom of Gapi, is one of the oldest and very influential kingdoms in the archipelago. Ternate has been visited by foreign traders such as those from China, Arabia and Gujarat, as well as those from the archipelago such as Java, Malacca, and Makassar. Ternate developed into the largest and main trading port in Maluku. Trade between nations at that time was centered at the port of Talangame, currently known as the port of Bastiong. Ternate already has a market with adequate facilities, where local traders, foreign traders and domestic traders meet (Rusdiyanto, 2018).

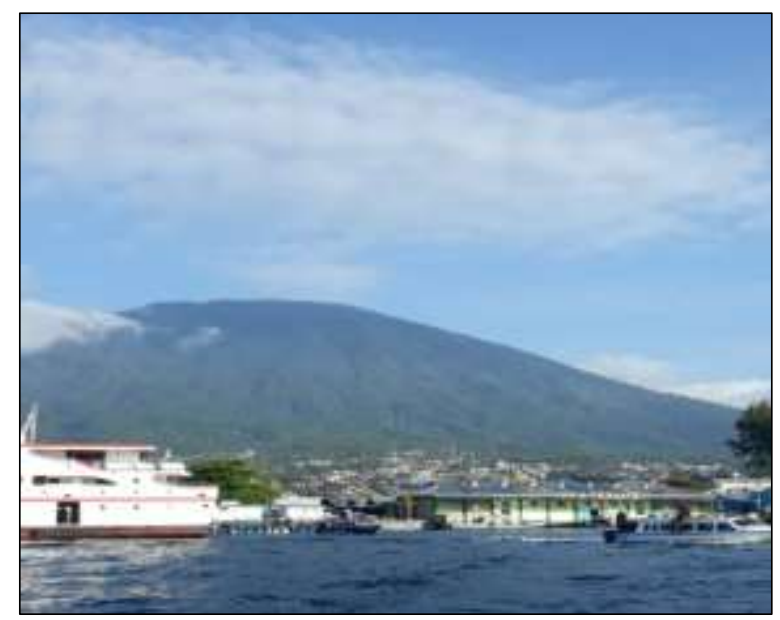

Figure 3: Bastiong Port (source: Personal Documentation)

Mulyadi (2016) cited that international merchant fleets came to this port mainly to look for spices, an important commodity in the international market at that time, which turned this group of islands into a busy commercial traffic lane. The rapid trade of spices caused the Moluccan Kings to compete with each other to consolidate their respective positions so that it often led to conflicts between them.

In the era of spice trade in Southeast Asia, shipping lines were formed to connect the production places to the market places. Recorded in the history of the spice-producing islands are the eastern part of the archipelago, such as Ternate, Tidore, Bacan, Ambon, and Banda Islands. Nusa Tenggara, formerly known as Lesser Sunda Islands, was also known as a producer of fragrant woody logs such as sandalwood and aloes. 
There were four main ports in North Maluku, namely Jailolo, Bacan, Ternate and Tidore. Tidore oversaw several cities in East Halmahera, Raja Ampat Islands, and West Irian; while Ternate oversaw cities in Banggai Islands, the east coast of north Sulawesi; Jailolo oversaw the ports on the west coast of Halmahera (Mulyadi, 2016).

Malay merchants said that God created Timor for sandalwood and Banda for mace (and nutmeg) and Maluku (north) for cloves, and these merchandise do not grow anywhere else in the world except in those places. This quote illustrates that the attractiveness of the spices - cloves and nutmeg - is the main impetus for the development of international trade in Southeast Asia. Plant experts claim that clove (Eugenia aromatica) only grows in Ternate, Tidore, Moti, Makian, and Bacan. Nutmeg and seed coat covering (mace) obtained from nutmeg trees (Myristica fragrans) are found on Banda Island (Mulyadi, 2016).

Related to the wealth of the spice, Astuti and Ramos (2012) proposed the branding "Ternate-Tidore: The Spice Islands". Branding is important to stimulate economic growth, in terms of urban planning. Brand strategy is an innovative way to encourage regional development. By implementing the "Critical City: Core \& Drivers Methodology", North Maluku can be formulated as a regional brand. The vision "The victory of spices" in Indonesia in the past will become the "biggest factory" in the future. The Ternate-Tidore brand: The Spice Islands "brand have an impact on advanced agriculture investment \& management by local farmers and developing agro-industrial investments and management by local entrepreneurs, good public services by local governments, supporting infrastructure for people and industry, natural and cultural events, strong brand and image. Branding will encourage the region to be stronger in terms of economy.

However, until now, the Ternate City branding has not yet been formulated, although efforts are being made to that effect. In connection with the Creative City Forum Conference and Magellhaen Cities Network activities, elements of bureaucrats, academics, and community leaders are at the stage of public testing to map the branding of Ternate City as the Zero Point of the Spice Route, while pioneering the struggle towards World Heritage Unesco (interview, September 2019).

This article tries to make recommendations regarding the Ternate City branding strategy through storytelling. Storytelling is one of the instruments to form city branding based on the City's Core Story model developed by Keskin, Akgun, Zehir and Ayar (2016).

\section{THEORETICAL FRAMEWORK}

City branding is a clear concept since it raises the fundamental issue of community identity and of credible messages both for local public opinion in general, and for other external audiences. Moreover, there are authors (Kavaratzis \& Ashworth, 2006; Stigel \& Frimann, 2006) who clearly raised a question mark on sustainability strategies of place branding, this becoming a real trendy topic in urban marketing. As Kavaratzis showed (2004), city branding implies a significant change of perspective on the whole marketing effort. City branding is understood as a means of achieving competitive advantage in order to increase inward investment and tourism, reaching community development, reinforcing local identity and identification of the citizens with their city and activating all social forces to avoid social exclusion and unrest. Or, such an understanding of city branding implies the need of strategy and vision, understood and shared by internal audiences that, for a city, are identified as being the residents and local authorities. 
City branding is built, according to Kavaratzis (2004), on two basic coordinates: city's identity and the value of the products and related services of the city itself. It is, in fact, what we see into the attributes considered for measuring instruments of city brands, as Anholt report (Anholt, 2011), where classification parameters are organised around the following items: presence, place, prerequisites, people, pulse and potential. City branding does not merely mean campaigns, but strategy, continuity and consistency as well.

Yavuz (2014) explain that destination branding can be defined as a way to communicate a destination's unique identity by differentiating a destination from its competitors (Morrison \& Anderson, 2002). Cai (2002) defines destination branding as "selecting a consistent element mix to identify and distinguish it through positive image building. A brand element comes in the form of a name, term, logo, sign, design, symbol, slogan, package, or a combination of these, of which the name is the first and foremost reference". Cai (2002) seems to point out that the brand name for destination is often fixed but the use of slogans and symbols is utilized to communicate the name of the destination with associated benefits (Daye, 2010). Cai (2002) also seems to focus on the tangible elements of the branding process. On the other hand, Schmitt and Simonson (1997) and Morgan, Pritchard, and Piggott (2002) point to the presence of both functional and emotional values to differentiate product and destination brands from generic products and services.

Destination brand focuses on the whole destination and it is about local people living in destination, tourism personnel, tangible and intangible values, practices, events and processes of destination. Like corporate brand, destination brand is a kind of organisation brand (Aaker, Fournier \& Brasel, 2004). Destination branding must be made very carefully because the brand is the identifier of the destination and is used to support destination communication. Destination brand communicates expectations of what the destination will deliver in terms of products, services, and tourist/visitor/customer experience.

"Stories" related with a destination branding, and "storytelling" serve as a tool for destination branding. Stories are such a common part of our lives that it is sometimes easy to overlook their central role in the way we communicate with each other, understand and make sense of the world and its events, and store our memories (Moscardo, 2010). The objective of this study is to open a road for studying the possibilities of using storytelling as a means of developing and marketing a destination brand.

Storytelling can be a tool for tourism marketing, and also can function as a way of convincing audients (Abrar, 2018). Also, it can function as a tool of the place identity formation (Dziedzic, 2019). Thus, storytelling is a fundamental part of a city's charm and a valuable tool to make the city readable to tourists, to attract new flows of visitors and to drive them to specific activities (Agostinelli, 2018). When speaking of Rome, the story telling is probably easy to frame: The Eternal City, built on the seven hills, covered in cobbled streets and enriched by invaluable cultural heritage sites. Over the centuries Rome has been the center of an Empire, a religious focal point, a major archaeological hub and an artistic limelight. Besides the imposing ruins from the Roman Empire, Rome hosts some of the most important works of art of the medieval age, Renaissance and the Baroque, Neoclassicism and even Fascist Architecture. Rome is the city of good food, good people and good weather; all summarized by the expression "La Dolce Vita".

Christin and Fiteriadi (2017) explain Bandros Bandung Tourism Promotion Board, which is choosing storytelling with the theme of urban legend: the reason for the accident because of the route traversed, and urban legend and usually we never get bored with the 
horror story because hearing something mystical that we have never seen directly is endless. In Indonesia, ghost stories have been countless because they are found in all corners of Indonesia.

Therefore, products that tell stories are no longer strange to consumers, since they know a great deal about them and the products that people associate with emotions and stories are called brands. So, many efforts could be made, such as using government social media as Information Dissemination Tool (Ika Karlina, 2018). The present paper offers an insight into this branding approach by combining theoretical considerations with numerous examples of brands which have already embraced this technique, with the aim of providing a better understanding of the process of storytelling in general and an assessment of its role, especially in relation to branding (Mucundorfeanu, 2018). Stories play an exceptionally important role in how people assign value to a place. People have both personal and common stories about places, which they then share with neighbours, friends, relatives and strangers. Taken together, all those stories essentially give a place to a kind of personality, individuality and identity. Every city has its special places, connected to exceptional people or where unusual or perhaps even inexplicable incidents took place or where a historical event made its mark. Those places in combination give the city its identity (Timmermans, Van den Goorbergh, Slijkhuis, \& Cilliers, 2013, p.39). Even humours can be a content for tourism communication (Roswati, Radhiah, Noor Asliza, \& Roslina, 2017).

So stories give places a certain value, and even less well-known places in a city can be associated with a story. For instance, local residents can talk about why certain speed bumps bring back pleasant memories for them because their children helped design the colourful mosaic pattern on the speed bumps. In sum, people use a place in a particular manner for a particular period of time, which means the place takes on a different value for them compared to other people who do not use that place or use it in a different fashion. Such places have a narrative value. This value is then converted by people into norms and standards, and also into emotions and dynamism, and this therefore affects the way people respond to a place. This narrative value ties in well with the interaction between people and their physical environment, something that was lacking in the concept of place making.

Recognizing the importance of storytelling and its implications in this study may lead to a strategic tool and advantage for destinations. From a marketing perspective, destinations might use elements of a story in their promotional materials. Destinations might also use the proliferation of internet tools to reach customers for sharing strong elements of stories. Yavuz (2014) detailed his findings as follows: (1) Stories related to a destination can be effectively used in theme development and promotion campaigns, (2) A storytelling approach can be used for strategic destination identity development, branding and marketing in long term, multi-actor and multi-level process, (3) In order to have impact on destination branding by storytelling, the destination management organization must establish active multidisciplinary group efforts in tourism industry, (4) In order to realise successful communication between visitors and destination, the stories must be transmitted by verbs, objects, experiences, places and characters, (5) Storytelling efforts may raise local community awareness and thus, they will be important for strategic destination identity development, branding and marketing, and (5) Stories can be used as a framework for organising destination components like transport, hotels and restaurants if they convey the core values of a destination. In this point, the stories turn out to be verbal and visual metaphors which represent the proposals. 
Storytelling approach has received little attention in the travel and tourism marketing context. But, destination marketing literature described the role of storytelling on destination image formation, travel intentions (Keskin, Akgun, Zehir, \& Ayar, 2016) and destination development (Mossberg, Therkelsen, Huijbens, Björk \& Olsson, 2011). This approach is usually used to create successful brand both on a corporate and on a product level. But, a city, just like a company, can also attract people, visitors, enterprisers, activities, and take an active role in world events. In this sense, a city needs to adopt the appropriate strategies in order to brand itself successfully, as Merrilees, Miller and Herington (2013) emphasised. Therefore, the city's brand building process could apply storytelling as an influential and valuable technique (Keskin, Akgun, Zehir \& Ayar, 2016).

Keskin, Akgun, Zehir and Ayar (2016) compose a formula to form a city story as a story telling application in preparing city branding. The concept of storytelling in previous studies could only show the role of storytelling in tourism marketing context. The role of a core story can be explored in the future in a different context. The Keskin formula was adapted by Keskin, Akgun, Zehir and Ayar, (2016) from Fog's Laboratory model referred to as the City's Core Story.

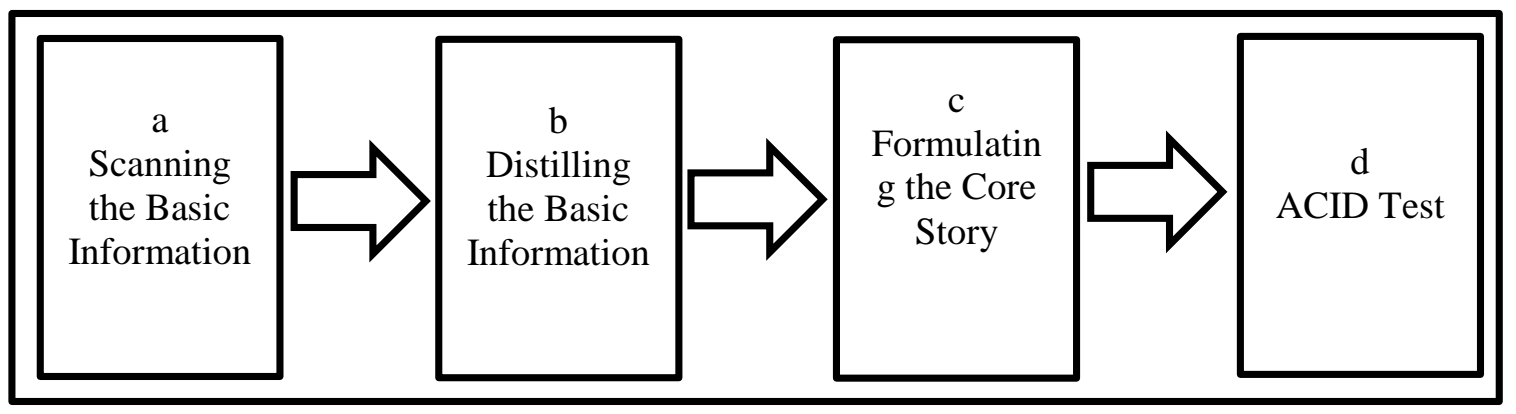

Figure 4: the City's Core Story (adapted from Keskin, Akgun, Zehir \& Ayar, 2016, p. 34)

From the figure, details as follows:

a. Scanning the Basic Information

Image that reflects the internal and external perceptions, experiences, impressions; and gained both from external and internal basic information.

\section{City's Vision, Mission and Values}

City mission and vision; values of the city; the expression of these values in real city life: the way the values shared internally and externally

Key Milestones in City's History

Historical process of the city, most significant event, narration living of the city

\section{Residents' Stories}

Stories narrated by residents about the city; representation of the city in some events and experiences; considering their city as a place to live and visit; residents' sense that the city is a special one. This is important, because as Hudak said (2019), resident stories are a form of citizen participation that can bind a sense of ownership of the branding of the region. 


\section{Global Tourism and Travel Trends}

Current global tourism and travel trends and their meaning in terms of the position of the city

\section{Visitors}

The role of visitors is very important in determining regional branding (Hsu, Dehuang, \& Woodside, 2009). Stories are repetitive visitors telling about the city; residents in other cities explaining about the city; position of the city compared to other cities at the international level; visitors targeted; identified their decisive motives to visit the city

\section{Travel Opinion Leaders}

Identify the opinion leaders in travel decision making and trip planning process; recommendation of travel agencies and social media (travel blogs and websites) about the city; review about the attractions, atmosphere, infrastructure and value of the city by those opinion leaders

\section{Partners}

The partners that have an active role in supporting and advising on strategies and practical issues; projects with those partners; the usage of those projects toward city's value

\section{b. Distilling The Basic Information}

When the internal and external information sources have been scanned, they need to cut to the quick and focus on the gist of what makes the city special (Fog, Budtz, \& Yakaboylu, 2005).

\section{c. Formulating The Core Story}

Formulating the core story consists of messages, conflict, cognitive and affective components, and the plot.

\section{d. The ACID Test}

The Acid Test investigates whether the city's core story is original regarding other cities. The branding can be viewed as a success if it is able to present core city values that are deemed coherent, distinguishing, attractive, enduring, and expressible (Kotler \& Gertner, 2002). Because a lot of cities have similar features to deliver, a strategy of city branding is to produce original values, so differentiating one city from another (Keskin, Akgun, Zehir \& Ayar, 2016)

\section{METHODOLOGY}

This research uses a qualitative descriptive approach with a case study method. Data collection was conducted by means of document studies, field observations, and in-depth interviews, while field data was collected in September 2019.

Case study is a series of scientific activities carried out intensively, in detail and indepth about a program, event, and activity, at the level of individuals, groups of people, institutions, or organisations to gain in-depth knowledge about the event. Usually, the events chosen, hereinafter referred to as cases, are actual (real-life events), which are taking place, not something that has passed (Raharjo, 2017). Cases are events, can be very simple or complex. Therefore, researchers choose only one that is truly specific. The event itself is classified as "unique". "Unique" means that it only occurs at a particular site or locus. 
To determine the 'uniqueness', Stake (2013) makes signs to be considered by researcher. These steps include: nature of the case itself, background of the case, physical setting of the case, the context surrounding, other cases that could explain the cases, and the informant who controls the case under study. He also noted that the case study has to question how and why instead of only asking 'what'. The "what" questions are intended to obtain descriptive knowledge, "how" to obtain explanative knowledge, and "why" to obtain explorative knowledge. Yin emphasizes the use of "how" and "why" questions, because both of these questions are considered very appropriate for gaining in-depth knowledge about the symptoms being studied. And they have to do with communication strategy (Maizatul Haizan, Wan Idros \& Wan Amizah, 2019). In this research, we applied the study case method to obtain descriptive knowledge of how storytelling could be used as city branding strategy. This case was unique because of the nature of Ternate itself.

\section{World Spice Trail}

\section{RESULT AND DISCUSSION}

Ternate is one of the most important places in the intellectual history of the world. At the height of the spice trade, Ternate is probably the most important island in the world. It competes with Tidore as the only source of cloves for the needs of the European market. A number of expeditions were carried out from Europe to develop the maritime spice route, from the west and east, even through the North Pole, to get this lucrative trade. The expedition of the spice route intended to find the north-western path through the North Pole and faced not only lot of glory but also a lot of wars. First were the Portuguese followed by Spanish, Dutch, English, Dutch and Japanese (Smith, 2014).

King Charles of Spain was eager to find the western route to the Spice Islands. He commissioned Magellan to form an expedition from 1519 to 1522 which was a journey around the first world. Although Magellan was killed in the Philippines, one of his surviving ships landed in Ternate in 1521 and returned home with a clove load which made the crew lucky. The previous agreement of Tordesillas 1494 divides the western hemisphere. The Portuguese built fortresses in Ternate and Tidore to protect their interests, but eventually Spain seized control (Utomo, 2017).

In past few years, the Flat Earth Discouse was raising, especially in social media. The debate about whether the Earth is round or flat surfaces throughout the world, one of which we can examine through cyberspace. Seconds inet explains the origins of the Flat Earth Society. Seconds inet said that the United States Military took a photograph of the earth in 1947 using a V-2 rocket and found the photo showing the earth has an arch, in the sense that the earth is round. However, Samuel Shenton refused to believe. He then founded the Flat Earth Society community in 1956 and its members believe that the earth is flat because it looks flat. This is the origin of the Flat Earth Society. According to the idea of the Flat Earth Society, the Earth is a flat disk with the Arctic at its center and a wall of ice that towers around it. The sun, moon and stars are said to be not far from New York and from London. Over the years, believers grew and spread, eventually gathering around 3,500 flat earthers in the 1990s. In 2004, the Flat Earth Society became a question and answer forum where they collected theories and evidence of flat earth. Coincidentally, in the same year Facebook was present in the Internet world. YouTube was launched a year later followed by Twitter. Flat Earth Society had its own website in 2009 and has started to dominate social media. 
This debate about Round Earth vs. Flat Earth could be the potential issue that can be used for the promotion of Ternate's tourism. Linking Ternate City as one of the stopover points in the Magelhaens Expedition is part of the evidence for the Round Earth Theory, which refutes the belief in the Flat Earth Theory. We can do such strategy of 'riding the waves' which is a marketing technique using viral issues. Ternate City can identify its identity and also sell tourism potential through historical and cultural stories. We also have to make maximum use of Instagram as storytelling venue (Shafizan, 2019).

The Round Earth vs. Flat Earth returns to Magelhaens Expedition on its journey to find spices. Precisely because there is this debate about Round Earth vs. Flat Earth, people recall the journey of spices and how all the struggles to find this spice were started by Europeans and then colored Indonesian history, specifically the history of Ternate. The story of this spice is a great potential to be developed as storytelling content in an effort to form a city branding strategy. Not many regions in the world have this potential history (Jolliffe, 2014)

\section{Wallace: History of Natural Sciences}

Rinto Taib (informant 1, interview, September 2019) stressed that Ternate's history has fulfilled the requirements for its inclusion in the UNESCO World Heritage Sites List. Being the zero point on the Spice Route is a sufficient reason. But it was also the center of biodiversity in the 19th century from which a number of recognised naturalists conducted their research. Most notable was Alfred Russel Wallace, who wrote his famous letter on the Theory of Evolution to Charles Darwin from his home in Ternate. This adds further support to the UNESCO list.

Wallace lived in Ternate for three years from 1869 to 1872 . He described his house in detail in his journal The Malay Archipelago. From this house on March 5, 1869 he posted the famous Ternate Letter to Charles Darwin who outlined his theory of evolution. His house is located in the Santiong area. Wallace mentioned the Portuguese Fort. Everyone (including Marzuki and Syamsil, 2008 in Winchup, 2000) agreed that what he meant was Fort Oranje, a Dutch fortress built on Portuguese and Spanish fortresses.

Experts began to lose track of Wallace. This was also complained by Prof. Sangkot Marzuki, Chairman of the Board of Management of the Wallacea Indonesia Foundation (according to Informant 1). This geneticist wrote a commentary in the Indonesian edition of The Malay Archipelago, the Archipelago (2009).

"Alfred Russel Wallace is a big name in the world of science. However, through the evidence, Wallace's legacy is palpable and easily identified that he is part of the history of the Indonesian nation ...," said Sangkot. "Ternate - where he had been working for a long time and where the real theory of evolution was born - was completely free of signs that reminded of the greatest discovery of the 19th century. Too bad."

In 2008, the Wallacea Foundation and the Indonesian Institute of Sciences had taken the initiative to erect the Wallace monument in the Paunga home yard. The aim was to raise the name of Wallace in Ternate. However, the monument has yet to materialise. The absence of an agreement on land prices between current home owners and the government has left the historical site neglected. The name of the road in front of the house has also been changed. The name of the street was changed to Jalan AR Wallace in 2008 from previously named Jalan Nuri. However, in 2010, the name was changed again to Juma Pusa Street until now (kompas.com). 
Davies (2012) explains the postulates of Van Wyhe and Rookmaaker (2012) in a series of events to support their claim that Wallace's 'evolution' letter, posted in Ternate in Maluku in the spring of 1858, arrived at Darwin's home on 18 June 1858. If their claim is proven, then the evidence that Darwin might have received Wallace's letter 2 weeks earlier than he ever claimed would clearly be wrong, and any accusation that he plagiarised Wallace's ideas from a letter would be proven wrong.

Here, evidence of this interpretation is presented and he argues that the letter did indeed arrive at the port of Southampton on 2 June 1858 and will be at Darwin's home near London the following day. If this is true, then 66 pages of new material on the Divergence aspect that Darwin entered into the 'big' species book in the weeks before acknowledging that he had received the letter could be interpreted as an attempt to present Wallace's ideas as his own.

\section{Storytelling as a Ternate City Branding Strategy}

What makes the power of storytelling and constitutes, at the same time, the main explanation for the fact that the branding and narratives are usually closely related, comes from the very essence of human appraisal of heroes, myths and extraordinary stories, in a sort of relation with the individual's expectations, experiences and feelings. Everyone, deep in his/her soul, wants to be proud of his/her life and to feel that it is important - this is the source of power and influence that can be achieved through storytelling (Simmons, 2002). Stories are related to feelings and emotions, representing, in essence, a chain of emotionally interlinked facts. This cultural story also plays a role in providing an understanding of the branding of urban areas that may not have strong roots because of the pluralism of its citizens (Jensen, 2007).

Timmermans et al. (2013) explained that storytelling can be a source of placemaking in the form of a story about a place. This can be an addition for successful city branding efforts, Kavaratzis (2004) suggests that it should answer the six key questions. The questions involve "(1) what the city definitely is; (2) what the city perceives it is; (3) what the city tells it is; (4) what the city is considered to be; (5) whom the city aims to serve; and (6) what is offered and anticipated?" On that basis, he shows that city branding can be interpreted within a 3-stage interaction model. The first stage expresses the tangible and visible sides from which a city can be observed. The second stage comprises promotion tools that a city introduces and adopts to market itself.

Finally, it is people's communication about a city through their voices (word and mouth, recommend) and social media (blogs, social networks). In the implementation of city branding, this multi-stage interaction model construct a utility pyramid, which composes of different levels of utility, including the tangible utilities to both residents and foreign people and the development of the city's reputation which comprises added value. This can also be strengthened by the use of digital and social media (Lambert, 2013; Lund, Cohen, \& Scarles, 2018; Martinus \& Chaniago, 2017).

Therefore, following is the model from Keskin, Akgun, Zehir and Ayar (2016), the Ternate Core's City Story as written below

\section{a. Scanning the Basic Information}

\section{City's Vision, Mission and Values}

The vision of Ternate City according to the Medium-Term Regional Development Plan (RJPMD) document, is developing Ternate into a city of culture, religion, harmony, 
independence, justice and environmentally friendly. Going forward, are as follows: (1) building Ternate as a fairly and prosperously independent city, (2) building Ternate as a cultural and religious city, (3) creating equitable service and trade infrastructure between urban areas, (4) building Ternate as a coastal and maritime city, and (5) building Ternate as a center of leading tourist destinations based on culture, history and maritime.

\section{Key Milestones in City's History}

The history of Ternate City, as described above, stretches from the time of the empire, to the period of colonialism, to the time of independence. This long and interesting history is partly the basis for developing tourism and becoming the city's identity.

\section{Residents' Stories}

The history of Ternate City, unlike other Heritage Cities, keeps the history of ordinary people, in the quest for Ali, Wallace's assistant when they lived in Ternate. Ali, as an ordinary person, became an important figure in the world when his role as Wallace's assistant helped to develop natural history.

In this study, we lack the time to identify external basic information regarding global tourism and travel trends, visitors, travel opinion leaders, and partners. However, regarding partners, Ternate City has become part of the Magellan's Cities Network, the Wallacean Foundation, the Indonesian Heritage City Network, and the Creative Cities Forum. Therefore, it should be used properly.

\section{b. Distilling The Basic Information}

Using the basic information, they need to cut to the quick and focus on the gist of what makes the city special (Fog, Budtz, \& Yakaboylu, 2005). The most important aspect in distilling the basic information process is to confirm the differences between Ternate City and any other Magellan's Cities, for instance. Also, from another maritime based ecotourism, another heritage city, another spices islands, another volcanoes island, and even from other World Spice Trail cities.

\section{c. Formulating The Core Story}

Formulating the core stories consist of messages, conflict, cognitive and affective components, and the plot. Messages include approaches to messages conveyed through brands. For example, Malaysia, Truly Asia. The city of Ternate, according to the data, intends to convey branding as the Zero Point of the World Spice Route.

The possible conflict raised is with a series of other World Spice Track cities in Indonesia, in particular, or in the World. For example, by promoting the conflict "The Zero Summit of Spice and the Miracle of Nature". If you want to explore past experiences from the point of the spice road, also enjoy the natural wonders of today in Ternate City.

Cognitive and Affective Components. In line with conflict, cognitive and affective experiences can be clashed through adventurous traces of past history that can be enjoyed at present.

The plot

As a part of the story, the storytelling plot of the Ternate City branding should show a flashback of the glory of Ternate's past with various traces of cultural heritage and its present role. It also added that by learning into the past, with the romanticism of memories, Ternate 
could become part of the pride of the nation. It is also important to form the plot about Wallace Story of Nature History and The World Spice Trail, the Magellan voyage, the Tordesillas Agreement and the Gold Glory and Gospel, extending up to the Flat Earth Issues

\section{d. The ACID Test.}

The Acid Test investigates whether the city's core story is original regarding other cities. Unfortunately, we don't have enough time to explore about the ACID test in case of Ternate City.

\section{CONCLUSION}

Storytelling is one of the instruments to form city branding. This study applies the City Core Story Model (Keskin, Akgun, Zehir \& Ayar, 2016, p.34) as a case study of the formation of the Ternate city branding strategy. The city of Ternate has suitable material for developing this storytelling method because of its historical and cultural richness, although in its regional planning this is not a priority. In our opinion, the most interesting thing is to develop the historical plot owned by Ternate in storytelling as a tool for city branding strategy, by compiling a plot as a part of the story.

The storytelling plot of the Ternate City branding should show a flashback of the glory of Ternate's past with various traces of cultural heritage and its present role. It also added that by learning into the past, with the romanticism of memories, Ternate could become part of the pride of the nation. It is also important to form the plot about Wallace Story of Nature History and The World Spice Trail, the Magellan voyage, the Tordesillas Agreement and the Gold Glory and Gospel, extending up to the Flat Earth Issues. We also need to make sure about sustainability of online reporting (Nazahah, \& Noorain, 2017).

\section{ACKNOWLEDGEMENT}

We would like to thank to Universitas Bakrie and Ministry of Research and Higher Education. This research is funded by the Ministry of Research and Higher Education through the scheme of PDUPT for budget year 2018-2019; contract number Kopertis 32/AKM/MONOPNT/2019 and Universitas Bakrie 148/SPK/LPP-UB/III/2019.

\section{BIODATA}

Eli Jamilah Mihardja, earned her Ph. D in environmental communication from Universiti Sains Malaysia, Penang. She is now a senior lecturer in Communication Study, Universitas Bakrie. Email: eli.mihardja@bakrie.ac.id

Tuti Widiastuti, earned her doctorate degree in Communication from Universitas Indonesia, Jakarta. She is now an associate professor in Communication Study, Universitas Bakrie. Email: tuti.widiastuti@bakrie.ac.id

Prima Mulyasari Agustini, earned her doctorate degree in Communication from Universitas Padjadjaran, Bandung. She is now an associate professor in Communication Study, Universitas Bakrie. Email: prima.agustini@bakrie.ac.id 


\section{REFERENCES}

Aaker, J., Fournier, S., \& Brasel, S. A. (2004). When good brands do bad. Journal of Consumer Research, 31(1), 1-16.

Abrar, A. N. (2018). Storytelling as a way of convincing audiences in environmental journalism. Jurnal Komunikasi Ikatan Sarjana Komunikasi Indonesia, 3(2), 84-90.

Agostinelli, A. (2018). Culture \& tourism in Rome: What is the future of the eternal city? A new storytelling to save the old history. Retrieved from: https://www.researchgate.net/profile/Alessia_Agostinelli2/publication/323855568_ CultureTourism_in_Rome_What_is_the_Future_of_the_Eternal_City_A_New_Storyt elling_to_Save the_Old_History/links/5aafcc66a6fdcc1bc0bd073f/Culture-Tourismin-Rome-What-is-the-Future-of-the-Eternal-City-A-New-Storytelling-to-Save-the-OldHistory.pdf

Akgün, A. E., Keskin, H., Ayar, H., \& Erdoğan, E. (2015). The influence of storytelling approach in travel writings on readers' empathy and travel intentions. Procedia-Social and Behavioral Sciences, 207, 577-586.

Anholt, S. (2011). 17. Beyond the nation brand: The role of image and identity in international relations. A. Pike, Brands and Branding Geographies, 289.

Astuti, Z. B., \& Ramos, R. A. (2012). Ternate-Tidore spice islands: A territory branding process. 8Th WSEAS (EEESD'12), Recent Researches in Environment, Energy Systems and Sustainability (pp. 243-248).

BAPPEDA Kota Ternate. (2012). Rencana pembangunan jangka menengah Kota Ternate.

Cai, L. A. (2002). Cooperative branding for rural destinations. Annals of Tourism Research, 29(3), 720-742.

Christin, M., \& Fiteriadi, M. (2017). Urban legend storytelling Bandung tour on the bus (Urban legend case study in Bandung through a spooky story on the bus). 3rd International Conference on Transformation in Communications 2017 (IcoTiC 2017). Atlantis Press.

Davies, R. (2012). How Charles Darwin received Wallace's Ternate paper 15 days earlier than he claimed: A Comment on Van Wyhe and Rookmaaker (2012). Biological Journal of the Linnean Society, 105(2), 472-477.

Daye, M. (2010). Challenges and prospects of differentiating destination brands: The case of the Dutch Caribbean islands. Journal of Travel \& Tourism Marketing, 27(1), 1-13.

Dziedzic, E. (2019). Storytelling as a tool of the place identity formation. Przedsiębiorczość $i$ Zarządzanie, 20(2, cz. 1 Marketing turystyczny), 109-119.

Erlangga, E. (2016). Faktor-faktor yang mempengaruhi terciptanya city branding sebagai upaya mempromosikan suatu kota: Studi kasus pada pemerintah Kota Ternate (Unpublished dissertation, Universitas Islam Negeri Alauddin Makassar).

Fog, K., Budtz, C., \& Yakaboylu, B. (2005). Branding through storytelling. Berlin: Springer.

Hasyim, R. (2019). Masyarakat dan kebudayaan Ternate dalam perspektif sejarah. Jurnal GeoCivic, 2(2).

Hsu, S. Y., Dehuang, N., \& Woodside, A. G. (2009). Storytelling research of consumers' selfreports of urban tourism experiences in China. Journal of Business Research, 62(12), 1223-1254.

Hudak, K. C. (2019). Resident stories and digital storytelling for participatory place branding. Place Branding and Public Diplomacy, 15(2), 97-108.

Jensen, O. B. (2007). Culture stories: Understanding cultural urban branding. Planning Theory, 6(3), 211-236. 
Jolliffe, L. (2014). Spices, cultural change and tourism. Spices and Tourism: Destinations, Attractions and Cuisines, 38, 1.

Ika Karlina Idris. (2018). Government social media in Indonesia: Just another information dissemination tool. Jurnal Komunikasi: Malaysian Journal of Communication, 34(4).

Kavaratzis, M. (2004). From city marketing to city branding: Towards a theoretical framework for developing city brands. Place branding, 1(1), 58-73.

Kavaratzis, M., \& Ashworth, G. J. (2006). City branding: An effective assertion of identity or a transitory marketing trick?. Place Branding, 2(3), 183-194.

Keskin, H., Akgun, A. E., Zehir, C., \& Ayar, H. (2016). Tales of cities: City branding through storytelling. Journal of Global Strategic Management, 10(1), 31-41.

Kompas.com. (2017, August 28). Rempah-rempah penyebab awal colonial di tanah air. Retrieved from https://travel.kompas.com/read/2017/08/28/170300027/rempahpenyebab-awal-kolonialisme-di-tanah-air

Kotler, P., \& Gertner, D. (2002). Country as brand, product, and beyond: A place marketing and brand management perspective. Journal of brand management, 9(4), 249-261.

Lambert, J. (2013). Digital storytelling: Capturing lives, creating community. NY: Routledge.

Lund, N. F., Cohen, S. A., \& Scarles, C. (2018). The power of social media storytelling in destination branding. Journal of Destination Marketing \& Management, 8, 271-280.

Maizatul Haizan Mahbob, Wan Idros Wan Sulaiman, \& Wan Amizah Wan Mahmud. (2019). Pengaruh komunikasi strategik ke atas keberkesanan penyampaian mesej. Jurnal Komunikasi: Malaysian Journal of Communication, 35(3).

Martinus, H., \& Chaniago, F. (2017). Analysis of branding strategy through Instagram with Storytelling in creating brand image on proud project. Humaniora, 8(3), 201-210.

Merrilees, B., Miller, D., \& Herington, C. (2013). City branding: A facilitating framework for stressed satellite cities. Journal of Business Research, 66(1), 37-44.

Mihardja, E. J., Bintoro, B. P. K., Putri, D. M., Widiastuti, T., Agustini, P. M., \& Adriati, F. (2019) Narration of development of ecotourism in instagram for city branding: Study in Pinrang regency. International Journal of Arts and Social Science, 2(4).

Morrison, A., \& Anderson, D. (2002, June). Destination branding. Paper presented at the Missouri Association of Convention \& Visitor Bureaus Annual Meeting, Lake of the Ozarks, MO.

Morgan, N., Pritchard, A., \& Piggott, R. (2002). New Zealand, 100\% pure. The creation of a powerful niche destination brand. Journal of brand management, 9(4), 335-354.

Moscardo, G. (2010). The shaping of tourist experience: The importance of stories and themes. In M. Morgan, P. Lugosi, \& J. R. B. Ritchie (Eds.), The tourism and leisure experience: Consumer and managerial perspectives (Vol. 44 of Aspects of Tourism, pp. 43-58). Buffalo, NY: Channel View Publications .

Mucundorfeanu, M. (2018). The key role of storytelling in the branding process. Journal of Media Research-Revista de Studii Media, 11(30), 42-54.

Mulyadi, Y. (2016). Kemaritiman, jalur rempah dan warisan budaya Bahari Nusantara.Talkshow Pekan Budaya Indonesia. Retrieved from https://www.researchgate.net/publication/315681395_Kemaritiman_Jalur_Rempah _dan_Warisan_Budaya_Bahari_Nusantara

National Geographic Society. (n.d.). Jun 7, 1494 CE: Treaty of Tordesillas. Retrieved from https://www.nationalgeographic.org/thisday/jun7/treaty-tordesillas/ 
Nazahah Rahim, \& Noorain Omar. (2017). Online communication and sustainability reporting: The managerial issues. Jurnal Komunikasi: Malaysian Journal of Communication, 33(3).

Olsson, A. K., Therkelsen, A., \& Mossberg, L. (2011). Making an effort for free - Volunteers' roles in destination-based storytelling. Current Issues in Tourism, 19(7), 659-679.

Pînzaru, F. M. (2012). From conjunctural urban storytelling to city branding: An empirical model for Bucharest. Management Research and Practice, 4(2), 44-44.

Raharjo, M. (2017). Studi kasus dalam penelitian kualitatif (Disertasi, UIN Maulana Malik Ibrahim, Malang).

Roswati Abdul Rashid, Radhiah Ismail, Noor Asliza Abdul Rahim, \& Roslina Mamat. (2017). Humour and communication in the tourism industry in Malaysia. Jurnal Komunikasi: Malaysian Journal of Communication, 33(1).

Rusdiyanto, R. (2018). Kesultanan Ternate dan Tidore. Aqlam: Journal of Islam and Plurality, 3(1).

Schmitt, B., \& Simonson, A. (1997). Marketing aesthetics: The strategic management of brands, identity, and image. NY: Free Press.

Shafizan Mohamed. (2019). Instagram and political storytelling among malaysian politicians during the 14th general election. Jurnal Komunikasi: Malaysian Journal of Communication, 35(3).

Smith, C. H. (2014). Wallace, Darwin and Ternate 1858. Notes and Records, 68(2), 165-170. https://doi.org/10.1098/rsnr.2013.0057

Simmons, A. (2019). The story factor: Inspiration, influence, and persuasion through the art of storytelling. Cambridge, MA: Basic books.

Stake, R. E. (2013). Multiple case study analysis. NY: Guilford press.

Stigel, J., \& Frimann, S. (2006). City branding-all smoke, no fire?. Nordicom Review, 27(2), 243-266.

Timmermans, W., van den Goorbergh, F., Slijkhuis, J., \& Cilliers, J. (2013). The story behind the place: Placemaking and storytelling. Van Hall Larenstein University of Applied Sciences. Retrieved from https://edepot.wur.nl/305049

Utomo, B. B. (2017). Asal-muasal dan terbentuknya jalur rempah. Abad: Jurnal Sejarah, 4(1), 6-16.

Whincup, P (2020). The quest for Alfred Russel Wallace's house on Ternate, Maluku Islands, Indonesia. Journal of the Royal Society of Western Australia, 103, 50-54.

Yavuz, M. C. (2014, July). Storytelling in tourism: Opportunities for the marketing and branding of Adana Destination. Conference of International Interdisciplinary BusinessEconomics Advancement Conference (IIBA), Istanbul, Turkey. 